\title{
Humor er et viktig \\ hjelpemiddel i palliativ behandling
}

Sykepleiere kan bruke humor som en mestringsstrategi i møte med døende pasienter. Et st $\varnothing$ ttende arbeidsmiljø er også essensielt for å kunne utøve god palliativ sykepleie.

Ida Kristine Strøm

Sykepleier

Gastrologisk sengepost, St. Olavs hospital

Beate André

Førsteamanuensis

Institutt for samfunnsmedisin og sykepleie, Senter for helsefremmende forskning, Norges teknisk-naturvitenskaplige universitet

Janna Halsetrønning

Fagutviklingssykepleier

Øya helsehus, Trondheim kommune

Palliasjon Humor Kommunikasjon

Sykepleien 2020108 (80299) (e-80299)

DOI: 10.4220/Sykepleiens.2020.80299

\section{Hovedbudskap}

Majoriteten av dødsfallene i Norge skjer enten på sykehjem eller sykehus. Dermed er det stor sannsynlighet for at helsepersonell blir involvert i palliativ behandling i løpet av yrkeskarrieren sin. Derfor er det viktig at de klarer å bruke seg selv terapeutisk i møte med pasienter i livets sluttfase. De må også vite hvordan de kan håndtere døden best mulig. 
I 2019 gjennomførte vi et prosjekt basert på

en kvalitativ intervju- og litteraturstudie. Prosjektet viser at gode kommunikasjonsevner er avgjørende for å kunne bruke seg selv terapeutisk.

Empati er en viktig egenskap helsepersonell må ha i møte med pasienter i livets sluttfase. Ved hjelp av humor og kommunikasjon kan helsepersonell skape en god relasjon med pasienten.

Humor kan også brukes som en strategi for å håndtere døden. Flere strategier som kom frem under prosjektet, var refleksjon, støttende arbeidsmiljø og godt samhold blant kollegene.

\section{Palliasjon}

Aktiv behandling, pleie og omsorg for pasienter med uhelbredelig sykdom og kort forventet levetid.

Kilde: Verdens helseorganisasjon

\section{Helsepersonell møter sin egen sårbarhet}

Innenfor sykepleiefaget er omsorg for døende og deres pårørende sentralt. I møte med døden er pasienter og pårørende i en sårbar og hjelpeløs situasjon (1). I sykepleie er hensikten å lindre pasientens fysiske og psykiske lidelser på best mulig måte og bidra til en verdig avslutning på livet (2).

Når helsepersonell gir palliativ behandling, møter de både sin egen, pasientens og pårørendes sårbarhet, siden døden betraktes som en av de største utfordringene for helsepersonell (3). Det vil derfor være viktig at helsepersonellet klarer å bruke seg selv terapeutisk samt håndterer døden på best mulig måte i møte med pasienter i livets sluttfase.

Dette prosjektet har tatt utgangspunkt i en palliativ avdeling i Trondheim kommune. Prosjektet skal belyse hvordan helsepersonell kan bruke seg selv terapeutisk i møte med pasienter i livets sluttfase. 


\section{Metode}

Prosjektet er basert på en intervju- og litteraturstudie. Vi samlet inn data i mars 2019 gjennom individuelle, semistrukturerte intervjuer.

\section{Intervju og utvalg}

Vi rekrutterte fire helsearbeidere, der begge kjønnene var representert. De hadde fra fem til 18 års erfaring med å jobbe med palliasjon. Gruppen av informanter besto av representanter fra ulike helseprofesjoner. I dette prosjektet er lege, sykepleiere og helsefagarbeidere omtalt som helsepersonell.

Før intervjuene utarbeidet vi en semistrukturert intervjuguide (4). Førsteforfatteren foretok intervjuene, som foregikk på et lukket samtalerom på avdelingen.

\section{Analyse}

Hvert intervju ble transkribert ordrett, og deretter ble teksten bearbeidet slik at den fikk en muntlig form. Vi analyserte intervjuene ved hjelp av en meningsanalyse og brukte en kombinasjon av meningskoding og meningsfortetning (4).

\section{Etiske overveielser}

Vi sendte ut et informert samtykkeskjema med informasjon om prosjektet på forhånd. Det var frivilling å delta på intervjuene, og deltakerne kunne når som helst trekke seg fra prosjektet. Prosjektet ble vurdert av Norsk senter for forskningsdata (NSD), prosjektnummer 58522, i 2018. Intervjuene ble anonymisert og behandlet konfidensielt (4).

\section{Resultat}

I intervjuene fortalte informantene om deres erfaring med å arbeide med pasienter i livets sluttfase. Funnene ble organisert i tre temaer og åtte undertemaer (tabell 1).

Tabell 1. Temaer og undertemaer

\begin{tabular}{ll} 
Tema & Undertema \\
\hline Eksterne faktorer & Arbeidsmiljø \\
& Debrifing \\
\hline Bruke seg selv terapeutisk & $\begin{array}{l}\text { Refleksjon } \\
\text { Kommunikasjon } \\
\text { Kunnskap }\end{array}$ \\
\hline Møte med mennesker & Død \\
& Humor \\
& Pårørende \\
\hline
\end{tabular}




\section{Eksterne faktorer}

\section{Arbeidsmiljø}

Felles for alle informantene var at de snakket positivt om arbeidsmiljøet på avdelingen, noe som hadde betydning for hvordan de håndterte $\mathrm{d} \varnothing \mathrm{den}:$ «Vi har et veldig bra arbeidsmiljø, veldig godt samhold.» (Informant 3)

Det var åpenbart at siden de jobber med palliasjon daglig, var det viktig å vise omsorg for sine kolleger: «Når man jobber med døden så tett, så tror jeg at det er viktig at vi tar vare på hverandre, vi som jobber her.» (Informant 1)

«Vi står ikke alene oppi dette, vi står sammen.» (Informant 3)

«Vi må stole veldig på hverandre, og vi jobber tett sammen om alvorlige ting, det er veldig viktig, tenker jeg. At vi er åpne og stoler på hverandre.» (Informant 4)

\section{Debrifing}

En faktor som kan hjelpe helsepersonell med å håndtere d $\varnothing$ den, er debrifing. En informant uttalte følgende:

«Det hender vi har debrifing, men ikke ved vanlige dødsfall, men hvis det er noen litt vanskeligere ting som skjer, at det blir mye styr, særlig ved vanskelige pårørendesituasjoner, der kan vi ha det.» (Informant 1)

\section{Bruke seg selv terapeutisk}

\section{Refleksjon}

Når informantene snakket om hvordan de kunne bearbeide vanskelige følelser, kom det frem at refleksjon var godt etablert på avdelingen: «Det er refleksjon i faste rammer. Men også hverdagsrefleksjon er viktig, for vi er nødt til å få ut ting, og det kan være små ting, bare det å høre på hverandre, og det gjør vi hver dag.» (Informant 1)

«Vi reflekterer over ting. Jeg går i egen refleksjonsgruppe en gang i måneden, så der er vi en fast gruppe. I tillegg prøver vi å ta det litt [...], det er ikke bestandig vi får tid til det, men vi prøver å ha en eller annenhver uke. Eller så tar vi det litt spontant.» (Informant 3)

«Jeg tenker at det er viktig å greie å koble ut jobben når du er hjemme, når du har fri. At du i alle fall ikke går og tenker på de lidelsene og de som dør hele tiden. Samtidig må man passe seg for at man på en måte ikke bryr seg, man må bruke det og vise at en er til stede når en er på jobb.» (Informant 4) 


\section{Kommunikasjon}

Kommunikasjon er en viktig del av det å arbeide med døende, både overfor pasienter, pårørende og kolleger. Under kommunikasjonen spiller også relasjon og empati en viktig rolle:

«Det var kommunikasjonsbiten som var vanskeligst i starten, og det å virke trygg på noe du ikke var trygg på. Jeg tror du må ha veldig gode kommunikasjonsevner. Men jeg tror det med å ha evnen til å tune seg inn på en situasjon, på et menneske, klare å ta inn hvor vedkommende er, veldig fort, det tror jeg er viktig.» (Informant 1 )

\section{$\equiv \ll$ Jeg tror du må ha veldig gode kommunikasjonsevner.»}

Informant

«Når du har pasienter som har vært her lenge, som du får tettere relasjoner til, det er av og til tøft. Du må tåle å stå i triste situasjoner, du må tåle å bli veldig nær på.» (Informant 2)

«Å være flink til å vise empati uansett, at man ikke trenger å anstrenge seg for å vise det, at det er naturlig.» (Informant 4)

\section{Kunnskap}

Helsepersonell som jobber med palliasjon, må ha god kompetanse innen faget sitt for å kunne gi god nok omsorg, men også for å få en helhetlig tilnærming til pasienten:

«Palliasjon handler mye om kompetanse, klinisk blikk og det å ha et klinisk blikk som funker. At man er litt i forkant, at man tar ting fort - for endringene skjer fort på disse pasientene.» (Informant 1)

«Kunnskap er viktig, det at jeg har kunnskap om palliasjon og det jeg møter, gjør meg mer trygg i arbeidet.» (Informant 2)

«Det er veldig viktig å ha god erfaring, for det er veldig mye av det man gjør, som bygger på erfaring. Det er jo en del spesialområder å jobbe med, [...] [men samtidig må] en se hele perspektivet.» (Informant 4) 


\section{Møte med mennesker}

\section{Død}

Når helsepersonellet snakket om døden, var det på en positiv måte. De så ikke på $\mathrm{d} \varnothing \mathrm{den}$ som forferdelig, men at den kunne være en positiv faktor:

«De aller fleste som kommer hit, har jo hatt lange sykehusopphold, lang behandling, mye styr og mange runder med opp- og nedturer, men mest nedturer, så døden kan jo være en befriende ting $i$ en sånn setting. Og det ser vi ofte, og da er det fint å kunne være en del av det.» (Informant 1)

«Jeg personlig ser på det at pasienten hadde et problem, kom hit, vi fikset det, gikk bort stille og rolig med pårørende rundt seg, så fint som det kan bli.» (Informant 2)

«Hvis enhver død skulle ha brakt meg ut av fatning, hadde det ikke gått å jobbe her. Døden er en del av livet.» (Informant 4)

\section{Humor}

Selv om mange ser på døden som noe trist, er humor en viktig del av palliativ omsorg. Humor gjør at stemningen på jobb ikke alltid blir så sorgtung og alvorlig, selv om pasientene har en alvorlig diagnose. Flere uttalte følgende:

«Det er en kjempeviktig avveining. Jeg hadde ikke orket å være her dersom det ikke hadde vært lov med humor.» (Informant 4)

\section{三 «Vi bruker mye humor i arbeidet, det er viktig at det gjøres på pasientens premisser.»}

Informant

«Galgenhumor. Og det som er morsomst, er at de fleste pasienter også har galgenhumor.» (Informant 2)

«Vi bruker mye humor i arbeidet, det er viktig at det gjøres på pasientens premisser.» (Informant 3 )

\section{Pårørende}

I arbeidet med palliasjon handler det ikke kun om å gi omsorg til pasienten, men også om å ta vare på de pårørende:

Det er pårørendebiten som kanskje er mest utfordrende. Det krever litt mengdetrening når man skal håndtere dette, for man kan ikke virke usikker i slike situasjoner.» (Informant 1) 
«De er veldig glade for å bli sett og få være med.» (Informant

4)

\section{Diskusjon}

Hensikten med denne studien var å unders $\varnothing$ ke hvordan helsepersonell kan bruke seg selv terapeutisk i møte med pasienter i livets sluttfase. Da er det også viktig at de ivaretar sine egne behov.

\section{Helsepersonell bruker seg selv terapeutisk}

Kommunikasjon inngår i det Travelbee kaller terapeutisk bruk av seg selv, hvor helsepersonell bevisst bruker personlighet og kunnskap for å bidra til positiv forandring hos den syke (5).

Funn fra intervjuene viser at gode kommunikasjonsevner er nødvendig i palliativ omsorg. Det ble nevnt at det var kommunikasjonsdelen som var vanskeligst i starten - å virke trygg på noe du ikke var trygg på.

Det kan hevdes at kommunikasjonsevner er noe man utvikler gjennom erfaring. Selv med lang erfaring kan helsepersonell ha utfordringer med kommunikasjonen som de må håndtere i løpet av yrkeskarrieren sin.

Endringer i tilstanden hos denne pasientgruppen skjer fort, det er derfor viktig med god klinisk kompetanse for å fange opp og møte disse endringene. Ved å håndtere disse utfordringene vil kommunikasjonsevnene og kunnskapsnivået utvikles, og dermed blir de tryggere i arbeidet.

\section{Gode kommunikasjonsferdigheter bør utvikles}

Dersom helsepersonell utvikler gode kommunikasjonsevner, skal de kunne klare å bruke seg selv terapeutisk i møte med pasienter i livets sluttfase. Dette krever at helsepersonellet er bevisst på sine sterke og svake sider, samt at de må kombinere empati med sine personlige egenskaper.

Ifølge Travelbee er det helsepersonellets empatiske holdning som er viktig (6). Dette synet sammenfaller med uttalelser fra informantene, som også vektla hvor viktig det var å ha empatiske holdninger. 
Empati er essensielt når helsepersonell gir omsorg til døende, i og med at helsepersonell skal prøve å forestille seg hvordan det er å være i den situasjonen pasienten er i (3). Dette er nødvendig for å klare å bruke seg selv terapeutisk, men kan også bidra til å skape en relasjon til pasienten og de pårørende.

Det er kommunikasjonen som legger grunnlaget for relasjonen mellom helsepersonellet og pasienten (3). På den palliative avdelingen er det høyt prioritert å skape en god relasjon og tillit til pasientene og de pårørende.

De må tåle å stå i triste situasjoner og komme tett innpå pasienten. En god relasjon bidrar til at de ser pasientens behov og behandler dem med en helhetlig tilnærming.

I intervjuene kom det også frem at de må tune seg inn på pasientens situasjon. En helhetlig tilnærming underbygges av det Travelbee mener er terapeutisk bruk av seg selv, at helsepersonell må ha evnen til å tolke egne og andres handlinger og iverksette tiltak på en effektiv og omsorgsfull måte (6). Ved hjelp av kommunikasjon kan de også bruke humor.

\section{Hvordan bruke humor terapeutisk?}

Humor er en del av det å bruke seg selv terapeutisk. Intervjuene viste at bruk av humor var godt etablert på avdelingen, både blant pasientene og kollegene. I lindrende behandling er humor en passende og nyttig ressurs, men det er viktig at den brukes på pasientens premisser, da ikke alle vil være mottakelige med tanke på deres alvorlige diagnose (11).

Informantene erfarte at mange av pasientene også har galgenhumor (7). På den ene siden kan humor være med på å skape en relasjon til pasienten, da humor kan gi følelsen av nærhet, samhørighet, varme og vennskap. På den andre siden kan den virke st $\varnothing$ tende hvis den blir brukt feil.

Humor er terapeutisk når helsepersonellet tar hensyn til pasienten og bruker humoren sammen med sin kompetanse og omsorg overfor pasientene. Den kan også brukes som en strategi for å håndtere hyppige møter med døden.

\section{«Humor kan være en god mestringsstrategi i møte med døende pasienter.»}


I intervjuene kom det frem at humor ble brukt som en avvergingsmetode. Humor kan brukes for å distansere seg fra alvoret, opptre muntert og styre unna sine egne vanskelige følelser (3).

I annen forskning kommer det frem at humor gjorde det mulig for helsepersonell å håndtere vanskelige følelser, samt at humor var en av de tre mest kraftfulle ressursene som beskyttet mot negativ påvirkning av $\mathrm{d} \varnothing \mathrm{den}(8,9)$.

Ved hjelp av humor kan også håp og engasjement formidles. Håp er viktig både for pasientene og helsepersonellet, slik at de kan klare å håndtere lidelse, sykdom og tap. Humor kan gjøre stemningen lettere, virke angstdempende og befriende på tross av pasientens alvorlige diagnose.

Gjennom kommunikasjon og humor kan sykepleieren vise engasjement og omsorg for pasientene. Humor kan være en god mestringsstrategi i møte med døende pasienter. Det er likevel viktig at helsepersonell får mulighet til å reflektere over de vanskelige situasjonene og bearbeide følelsene.

\section{Helsepersonellets behov må ivaretas}

Dersom helsepersonell skal kunne klare å bruke seg selv terapeutisk i møte med pasienter i livets sluttfase, må de altså få bearbeidet følelsene sine. Det vil være vanskelig å kunne ivareta den sykes behov dersom egne behov blir tilsidesatt. Helsepersonell må derfor få reagere eller avreagere, da møtet med døden er utfordrende (6).

Informantene fortalte at de hadde refleksjon på timeplanen, både i faste rammer og i hverdagen. Det ble også nevnt debrifing, som er en gruppesamtale, noe refleksjon også kan være. Når de har faste refleksjoner, møtes en gruppe for å snakke ut om sine følelser og tanker, noe man også gjør ved debrifing.

Det at kun én nevnte debrifing, kan være fordi de andre ser på det som refleksjon, og at debrifing er noe som kun gjennomføres ved spesielle, vanskelige situasjoner etter et dødsfall. De kan se på debrifing som noe større og mer formelt enn refleksjon. 
Formålet med debrifing er å forhindre negative, psykiske senfølger, og det er nettopp dette som også er formålet med refleksjon (10). Uansett vil både debrifing og refleksjon være med på å få bearbeidet vanskelige følelser og kan gjøre mennesker i stand til å åpne seg og føle samhørighet og tilknytning til hverandre (3). Debrifing hjelper helsepersonellet med å reflektere og bearbeide følelser og opplevelser som kan være utfordrende.

Helsepersonell må ha evne til å bry seg om pasienten, føle omsorg og kunne omsette omsorgsevnen til handling $\mathrm{i}$ situasjoner der det trengs (6).

Dersom de kommer i situasjoner som virker sterkt inn på dem, kan det være nødvendig å distansere seg for å kunne fokusere på behovene til pasienten. Da kan de klare å bruke seg selv terapeutisk i møte med pasienter i livets sluttfase.

Det er viktig at helsepersonell gis anledning til å dele sine tanker med kolleger om det de erfarer for å dra nytte av sine erfaringer og bruke dem aktivt i møte med nye pasienter (11). Hvordan de klarer å håndtere døden, har betydning for deres evne til å oppfatte, respondere på og vise omsorg for det døende mennesket (6).

En negativ følge av at helsepersonell ikke får arbeidet seg gjennom vanskelige følelser, er at de kan bli utbrent. Derfor er det viktig at de får snakket ut om sine følelser for å utvikle sin personlige og faglige identitet (11).

\section{Ansatte må ta vare på hverandre også}

Intervjuene viser at denne palliative avdelingen har et godt arbeidsmiljø og samhold, noe som har betydning for hvordan de håndterer døden samt bruker seg selv terapeutisk. Informantene fortalte at det var viktig å være åpen, kunne stole på og ta vare på hverandre.

\section{三 «t godt arbeidsmiljø hjelper med å håndtere utfordringene i møte med døden.»}

Det å ta vare på hverandre st $\varnothing t t e s$ av Travelbee, som mener at helsepersonell må ha evnen til å bry seg om og føle omsorg for individet (6). Det å stole på kollegene kan bidra til en opplevelse av fellesskap og samhold (12). I intervjuene ble det nevnt at et godt arbeidsmiljø hjelper med å håndtere utfordringene i møte med døden. 
Årsaken kan være at de tør og har muligheten til å snakke ut om følelser og tanker med sine kolleger. På denne avdelingen bruker de hverandre og passer på hverandre, noe som har betydning for hvordan de håndterer møtet med d $\varnothing$ den, lærer av sine egne og andres feil samt klarer å bruke seg selv terapeutisk.

\section{Styrker og svakheter med prosjektet}

Vi intervjuet fire informanter som alle jobbet på samme avdeling. Det kan derfor være vanskelig å generalisere disse resultatene, men funnene støttes likevel av forskning og annen litteratur.

\section{Konklusjon}

Denne studien viser at i palliativ behandling er humor et viktig hjelpemiddel, både for helsepersonell, pasienter og pårørende. Humor kan brukes for å skape en relasjon, men også som en mestringsstrategi for å håndtere hyppige møter med døende pasienter.

Empati er en viktig egenskap som helsepersonell må ha overfor pasienter i livets sluttfase. Helsepersonell må ha empatiske holdninger for å kunne bruke seg selv terapeutisk.

Funnene tyder på at gode kommunikasjonsevner er nødvendig, og gjennom kommunikasjon legges grunnlaget for en god relasjon. Denne relasjonen er avgjørende for å kunne se pasientens behov og behandle døende med en helhetlig tilnærming.

Refleksjon og debrifing er viktig for å få bearbeidet vanskelige følelser. Det er av vesentlig betydning at det i fremtiden blir lagt vekt på at helsepersonell får hjelp og tid til refleksjon, har et støttende arbeidsmiljø og et godt samhold blant kollegene.

\section{Referanser}

1. Henderson V. Basic principles of nursing care. Amer Nurses Pub; 1997.

2. Mathisen J. Sykepleie ved livets avslutning. I: Grimsb $\varnothing \mathrm{GH}$, red. Grunnleggende sykepleie. Bind 3. 3. utg. Oslo: Gyldendal Akademisk; 2016. s. 407-49.

3. Kalfoss MH. Møte med lidende og døende pasienter sykepleierens møte med seg selv. I: Almås H, red. Klinisk sykepleie 2. 5. utg. Oslo: Gyldendal Akademisk; 2016. s. 45379. 
4. Dalland O. Metode og oppgaveskriving. 5. utg. Oslo:

Gyldendal Akademisk; 2012.

5. Kirkevold M. Sykepleieteorier - analyse og evaluering. 2. utg. Oslo: Gyldendal Akademisk; 1998.

6. Travelbee J. Mellommenneskelige forhold i sykepleie. Oslo: Gyldendal Akademisk; 2001.

7. Linge-Dahl LM, Heintz S, Ruch W, Radbruch L. Humor assessment and interventions in palliative care: a systematic review. Front Psychol. 2018;19(9):890. DOI:

10.3389/fpsyg.2018.00890

8. Cain CL. Integrating dark humor and compassion: identities and presentations of self in the front and back regions of hospice. J Contemp Ethnogr. 2012;41(6):668-94.

9. Müller M, Pfister D, Markett S, Jaspers B. Wie viel Tod verträgt das Team? Eine bundesweite Befragung der Palliativstationen in Deutschland. Schmerz. 2009;23(6):6008.

10. Malt U. Debrifing [Internett]. Store medisinske leksikon. 2018 [oppdatert 14.10.2019, sitert 02.05.2019]. Tilgjengelig fra: https://sml.snl.no/debriefing

11. Iranmanesh S, Häggström T, Axelsson K, Sävenstedt S. Swedish nurses' experiences of caring for dying people: a holistic approach. Holist Nurs Pract. 2009;23(4):243-52.

12. Zambrano SC, Chur-Hansen A, Crawford GB. The experiences, coping mechanisms, and impact of death and dying on palliative medicine specialists. Palliat Support Care. 2014;12(4):309-16. 